EL MUHASABA: Jurnal Akuntansi (e-Journal)

Volume 12 , No. 2, Tahun 2021

P ISSN: 2086-1249 ; E ISSN: 2442- 8922

\title{
MEMAKNAI IMPLEMENTASI CORPORATE SOCIAL RESPONSIBILITY MENUJU SUSTAINABILITY DALAM PERSPEKTIF SOCIAL PRACTICE BOURDIEU
}

\author{
Sulis Rochayatun \\ Universitas Islam Negeri Maulana Malik Ibrahim Malang \\ Jl. Gajayana No 50 Malang \\ e-mail:sulis@uin-malang.ac.id \\ Universitas Negeri Malang \\ Jl. Semarang No 5 Malang, 65145 \\ e-mail : sulis.rochayatun.2004139@students.um.ac.id
}

\begin{abstract}
This study aims to interpret the implementation of CSR in achieving corporate sustainability studied with Bourdieu's social practice theory. This study uses an interpretive paradigm with a phenomenological approach. The research location is PT. Tirta Investama - Pasuruan Keboncandi Factory. Data collection was carried out by conducting in-depth interviews with key informants who took turns to obtain data triangulation.

The results showed that the implementation of CSR on the research site was well organized and structured and became a permanent and incidental program. CSR is implemented based on the principle of "dual commitment", which is the belief that if a company wants to be successful in business, the company must be successful socially. The process of defining and understanding CSR towards corporate sustainability is pursued by forming a habitus, maintaining the existence of capital and mastering the field, this is in line with Bourdieu's concept of social practice.
\end{abstract}

Keyword: Corporate Social Responsibility, Corporate Sustainability, Social Practice Bourdieu

\begin{abstract}
Abstrak
Penelitian ini bertujuan untuk memaknai implementasi CSR dalam meraih keberlanjutan perusahaan dikaji dengan teori social practice Bourdieu. Penelitian ini menggunakan paradigma intepretive dengan pendekatan fenomenologi. Lokasi penelitian adalah PT. Tirta Investama-Keboncandi Plant Pasuruan. Pengumpulan data dilakukan dengan melakukan wawancara mendalam dengan para informan yang dilakukan secara bergantian untuk mendapatkan triangulasi data. Hasil penelitian menunjukkan bahwa pelaksanaan CSR pada situs penelitian, sudah tertata dan terstruktur dengan baik dan menjadi program tetap dan insidental. CSR dilaksanakan berdasarkan prinsip "Dual Commitment" yaitu keyakinan bahwa jika perusahaan ingin sukses dalam bisnis maka perusahaan harus sukses dalam sosial. Proses pemaknaan dan pemahaman CSR menuju keberlanjutan perusahaan diupayakan dengan pembentukan habitus, menjaga keberadaan modal dan menguasai field, hal ini sejalan dengan konsep social practice Bourdieu.
\end{abstract}

Kata Kunci : Corporate Social Responsibility, Corporate Sustainability, Social Practice Bourdieu

\section{PENDAHULUAN}

Corporate Social Responsibility (CSR) dalam sejarah modern, semakin dikenal sejak Howard R. Bowen menerbitkan bukunya berjudul "Social Responsibilities of the 
Bussinesman" yang terbit pada tahun 1953 (Bowen, 2018). Sejak tahun 1970, istilah CSR mulai digunakan dan diperluas tentang perlunya dunia usaha meningkatkan kualitas hidup masyarakat agar menjadi penunjang eksistensi perusahaan (Carroll, 1999). Selanjutnya, CSR semakin populer dengan kehadiran buku karya John Elkington “ Cannibals With Forks : The Tripple Bottom Line in 21st Century Bussiness". Dalam bukunya tersebut, Elkington mengemas CSR dalam fokus 3P yaitu : Profit, Planet, People. Menurutnya, perusahaan yang baik tidak akan hanya memburu keuntungan ekonomi, belaka, melainkan memiliki pula kepedulian terhadap kelestarian lingkungan dan kesejahteraan masyarakat (Marrewijk, 2003)

Definisi CSR mengacu pada kebijakan dan tindakan organisasi, kebijakan dan tindakan tersebut dipengaruhi dan dilaksanakan oleh para pelaku di semua tingkat analisis, misalnya: kelembagaan, organisasi, dan individu (Aguinis \& Glavas, 2012). Penerapan konsep CSR mengalami perubahan pertumbuhan konsep, yang pertama didasarkan pada konsep filantropi, kemudian diubah menjadi konsep stakeholder, dan terakhir menjadi konsep modal sosial (Hidayah \& Khafid, 2016). Konsep yang memberikan solusi yang saling menguntungkan, meningkatkan keuntungan, dan menjaga keberlanjutan kinerja perusahaan dalam jangka panjang. (Bruch \& Walter, 2005).

Berdasarkan konsep stakeholder, perusahaan didorong untuk melaksanakan CSR fokus pada pemangku kepentingannya dengan tetap menjaga visi ekonomi, lingkungan, dan sosial. Dengan demikian, faktor kunci pencapaian kinerja perusahaan adalah kepuasan stakeholders (Perrini et al., 2007). Sementara itu, ada konsep lain yang memahami CSR sebagai modal sosial. Konsep ini memandang bahwa CSR memiliki hubungan yang erat dengan beberapa aspek, seperti niat baik, transparansi, dan kewarganegaraan yang baik. (Spence, 2007) Konsep modal sosial merupakan konsep yang lebih lengkap dan mencakup semua elemen, tidak hanya berfokus pada pemangku kepentingan tetapi juga memperhatikan niat baik, transparansi, dan kewarganegaraan yang baik. Konsep modal sosial dapat digunakan untuk membuat strategi perusahaan yang lebih baik. (Russo \& Perrini, 2010).

Corporate Social Responsibility (CSR) berhubungan erat dengan Corporate Sustainability (CS). Untuk mewujudkan keberlanjutan perusahaan diperlukan adanya CSR, sehingga perusahaan bisa beroperasional dengan tetap memperhatikan kelestarian lingkungan untuk generasi mendatang, serta peduli terhadap kesejahteraan masyarakat luas (Pomare, 2018). CS merupakan pendekatan yang bertujuan untuk menciptakan nilai pemangku kepentingan jangka panjang melalui penerapan strategi bisnis yang berfokus pada dimensi etika, sosial, lingkungan, budaya, dan ekonomi dalam berbisnis

Banyak penelitian telah membahas konsep CSR dan sustainability (Aguinis \& Glavas, 2012; Alijani \& Karyotis, 2016; Baumgartner, 2014; Chen \& Wongsurawat, 2011; Clara C. Romero \& L. Lamadrid, 2014; Griffin \& Sun, 2018; Handayati et al., 2017; Huda et al., 2018; Marrewijk, 2003) dan mengaitkan dengan budaya perusahaan, teori legitmasi, teori stakeholder, tetapi masih sedikit yang mengaitkan dengan konsep social practice Pierre Bourdieu. Hal ini menggugah oeneliti untuk melakukan kajian lebih lanjut tentang implementasi CSR dikaji dengan teori social practice Bourdieu. (Aaken et al., 2012) mengembangkan pendekatan baru untuk studi CSR berdasarkan teori praktek sosial Pierre Bourdieu. Menurut pendekatan ini, kegiatan pro-sosial dikonseptualisasikan 
sebagai praktik sosial yang digunakan oleh manajer individu dalam perjuangan pribadi mereka untuk mendapatkan kekuasaan sosial. Pierre Bourdieu merumuskan 3 konsep dalam "social practice" yaitu, habitus, capital dan field" (Webb et al., 2020). Bourdieu merumuskan konsep habitus sebagai analisis sosiologis dan filsafati atas perilaku manusia.

Pada kajian pelaksanaan CSR Jawa Timur, dimana peneliti terlibat di dalamnya ditemukan hasil hampir seluruh perusahaan yang disurvey sejumlah 278 perusahaan, hampir 99\% sudah melakukan CSR, tetapi tidak semua perusahaan memiliki program CSR yang tersusun dan terprogram secara baik. Salah satu perusahaan yang sudah memiliki program CSR yang terstruktur dan mapan adalah PT. Tirta Investama. Pelaksaaan CSR di PT Tirta Investama yang sudah terprogram dengan baik justru memotivasi penulis untuk melanjutkan penelitian yang lebih mendalam tentang bagaimana perusahaan memaknai dan melaksanaan program CSRnya dan mendalami bagaimana konteks sustainability yang seharusnya melekat dalam CSR. Penelitian ini bertujuan untuk memaknai implementasi CSR dalam meraih keberlanjutan perusahaan dikaji dengan teori social praktice Bourdieu.

\section{KAJIAN PUSTAKA}

\section{Corporate Social Responsibility}

Konsep corporate social responsibility (CSR) memiliki sejarah panjang terkait dengan bagaimana dampaknya pada perilaku organisasi. CSR adalah gagasan yang diperdebatkan karena sering dikaitkan dengan individu daripada lembaga (Schaltegger et al., 2006). Untuk memahami dampak CSR terhadap perilaku organisasi, maka perlu dipahami perkembangannya, (Moura-Leite \& Padgett, 2011) menelusuri evolusi konseptual CSR dari dekade ke dekade dan menunjukkan bahwa CSR telah berubah secara terus menerus selama 60 tahun terakhir.

CSR sebagai sebuah konsep muncul dalam konteks bisnis, menjadi konsep yang populer baik dalam praktik manajemen maupun dalam penyelidikan akademis dari tahun 1970-an (Carroll, 1999). Matten dan Moon (2008) memperkenalkan perbedaan konsep CSR implisit dan eksplisit. CSR cenderung eksplisit, yaitu dikodifikasi sebagai kebijakan perusahaan yang secara eksplisit dirumuskan oleh perusahaan, atau implisit, yaitu dikodifikasi sebagai kerangka kelembagaan yang secara implisit diasumsikan oleh perusahaan. (Matten \& Moon, 2008).

Dasar pemikiran CSR tidak lagi dipertanyakan, dengan perdebatan malah berfokus pada karakteristik model CSR terintegrasi terbaik yang mampu memenuhi pluralitas tuntutan yang ada (McWilliams \& Siegel, 2000). Keberhasilan jangka panjang perusahaan, dan kapasitas mereka untuk menghasilkan nilai, sekarang dianggap dipengaruhi oleh kapasitas yang mereka tampilkan untuk bertindak secara bertanggung jawab, menghormati semua pemangku kepentingan dan lingkungan alam (Burke \& Logsdon, 1996; Chen \& Wongsurawat, 2011; Freeman \& McVea, 2005)

\section{Corporate Sustainability}

Corporate Sustainability (CS) telah menjadi bagian dari bahasa komunitas bisnis di seluruh dunia. Asal mula konsep CS terutama terkait dengan definisi "pembangunan 
berkelanjutan" dalam laporan Brundtland (1987) dan mencakup penggabungan triple bottom line - kemakmuran ekonomi jangka panjang, keadilan sosial, dan tanggung jawab lingkungan - ke dalam operasional perusahaan. praktek dan manajemen (Antolín-López et al., 2016). Demikian juga, CS juga telah didefinisikan sebagai pendekatan multi-kriteria heuristik yang disusun oleh dimensi kinerja ekonomi, sosial dan lingkungan (Schaltegger et al., 2006). Berbagai pemangku kepentingan, seperti peneliti, investor, pelanggan, pemerintah, dan masyarakat sipil sekarang tidak hanya memperhatikan kinerja ekonomi perusahaan tetapi juga kinerja sosial dan lingkungan mereka (Freeman \& McVea, 2005).

Peran bisnis mengenai pembangunan berkelanjutan biasanya didiskusikan sebagai 'tanggung jawab' kepada masyarakat,dimana tanggung jawab didefinisikan sebagai kebutuhan untuk menghilangkan efek negatif dari bisnis. Ini adalah pendekatan defensif. Juga pertanyaan tentang bagaimana bisnis dapat secara aktif berkontribusi pada tujuan pembangunan berkelanjutan, untuk menghubungkan tanggung jawab dengan peluang, sangat relevan. Dalam hal ini pembangunan berkelanjutan akan menjadi sumber penciptaan nilai - untuk perusahaan dan masyarakat (McWilliams \& Siegel, 2011). Meski demikian, keberlanjutan perusahaan akan selalu spesifik untuk setiap organisasi (Baumgartner, 2014).

\section{Teori Sosial Practice Bourdieu}

Berdasarkan teori praktek sosial Pierre Bourdieu, (Aaken et al., 2012) mengembangkan pendekatan baru untuk studi CSR. Menurut pendekatan ini, kegiatan pro-sosial dikonseptualisasikan sebagai praktik sosial yang digunakan oleh manajer individu dalam perjuangan pribadi mereka untuk mendapatkan kekuasaan sosial. Bourdieu menempatkan praktik sosial, yaitu aktivitas yang berbentuk sosial (Handayati et al., 2017; Wapshott, 2017) yang dilakukan oleh aktor individu sebagai pusat analisisnya. Menurut Bourdieu, (Krisdinanto, 2016) motif individu untuk melakukan praktik tertentu adalah untuk meningkatkan modalnya karena hal ini memungkinkan aktor individu untuk menghasilkan kekuasaan. Dunia sosial merupakan praktik sosial. Bourdieu menyodorkan rumus generatif tentang praktik sosial dengan persamaan: $($ Habitus $\times$ Modal $)+$ Arena $=$ Praktik sosial

Habitus adalah hubungan tidak hanya antara masa lalu, sekarang dan masa depan, tetapi juga antara sosial dan individu, obyektif dan subyektif dan struktur dan agensi (Hobsbawm, 2016). Bagi Bourdieu, habitus merupakan sistem yang tahan lama, melalui transisi, terstruktur dan cenderung sebagai prinsip penataan praktik sosial dan dapat secara obyektif diatur menjadi produk ketaatan pada aturan dan disesuaikan dengan tujuan (Bourdieu, 1985). Dalam bahasa lebih sederhana, George Ritzer menyebut habitus sebagai "struktur mental atau kognitif" yang digunakan aktor untuk menghadapi kehidupan sosial. (George Ritzer-Douglas J. Goodman, 2005).

Dalam Pierre Bourdieu, tradisi Marxian, bentuk-bentuk modal didefinisikan dengan merujuk pada penguasaan ekonomi. Menurut Bourdieu, kekuatan-kekuatan sosial yang fundamental berdasarkan hasil penyelidikan empirisnya, pertama-tama adalah kapital ekonomi, dalam berbagai jenisnya; kedua modal budaya atau lebih baik, modal informasional, lagi-lagi di dalamnya jenis-jenis yang berbeda; dan ketiga dua bentuk modal yang berkorelasi sangat kuat, modal sosial, yang terdiri dari koneksi berbasis 
sumber daya dan keanggotaan grup, dan modal simbolik, yaitu bentuk berbagai jenis modal yang diambil setelah dianggap dan diakui sebagai modal yang sah (Bourdieu, 1983). Modal sosial termanifestasikan melalui hubungan-hubungan dan jaringan hubungan-hubungan yang merupakan sumber daya yang berguna dalam penentuan dan reproduksi kedudukan-kedudukan sosial (Krisdinanto, 2016)

Konsep habitus tidak bisa dipisahkan dari apa yang disebut Bourdieu sebagai field (ranah). Ranah dalam istilah analitik, dapat didefinisikan sebagai jaringan, atau konfigurasi, hubungan obyektif antara posisi. Posisi-posisi ini didefinisikan secara obyektif, dalam keberadaan mereka dan dalam penentuan yang mereka paksakan kepada pihak-pihak yang terkait, agen atau institusi mereka, dalam struktur distribusi spesies kekuasaan (atau modal) yang kepemilikannya memerintahkan akses. dengan keuntungan spesifik yang dipertaruhkan di lapangan, serta oleh hubungan obyektif mereka dengan posisi lain (dominasi, subordinasi, homologi, dll.) (Jenkins, 1992).

\section{METODE}

\section{Jenis dan Paradigma Penelitian}

Penelitian ini merupakan jenis penelitian kualitatif dengan paradigma interpretif yang bertujuan memperoleh pemahaman dan pemaknaan terkait implementasi CSR di PT Tirta Investama. Penelitian kualitatif menurut Creswell, dimulai dengan asumsi, pandangan dunia, kemungkinan penggunaan lensa teoritis dan menyelidiki arti individu dan kelompok yang dianggap berasal dari masalah sosial (Creswell, 2009). Berdasarkan hal tersebut, penelitian ini dimulai dengan asumsi pelaksaaan CSR di PT Tirta Investama, kemudian di interpretasikan dengan menggunakan perpektif teori social practice Bourdieu.

Paradigma yang digunakan adalah interpretif dengan pendekatan fenomenologi, untuk menggambarkan dan menjelaskan serta mengungkap makna bagaimana pelaku dalam perusahaan memahami pelaksaaan CSR di perusahaan sebagai upaya untuk memperoleh keberlanjutan perusahaan. Fenomenologi merupakan studi yang mendeskripsikan sebuah obyek, konsep maupun fenomena (Creswell, 2007). Fenomena bahwa pelaksanaan CSR di PT Tirta Investama bisa berjalan dengan baik, dengan program yang sudah tersusun rapi menjadi fenomena menarik untuk diteliti.

\section{Situs, Informan dan Metode Pengumpulan Data}

Penelitian ini menggunakan PT Tirta Investama - Keboncandi Plant Pasuruan sebagai situs penelitian, merupakan pabrik air mineral dengan brand "aqua" dan berada dalam naungan Danone Indonesia. Adapun obyek yang dianalisis adalah pemahaman mengenai implementasi CSR untuk meraih keberlanjutan perusahaan.

Untuk mendapatkan informasi yang tepat sesuai dengan tujuan penelitian, beberapa informan kunci dan pendukung digunakan dalam penelitian ini. Adapun informan dalam penelitian ini meliputi pihak internal perusahaaan yaitu : eksternal stakeholder manager, plant manager, CSR manager, HRD manager dan pihak eksternal perusahaan yaitu : mitra NGO, mitra pendamping CSR dan kepala desa setempat.

Pengumpulan data dilakukan dengan melakukan wawancara mendalam dengan para informan yang dilakukan secara bergantian untuk mendapatkan triangulasi data. Pengumpulan data dilakukan dalam kurun waktu selama lima bulan dengan kunjungan intensif kepada para informan. Wawancara dilakukan secara tidak terstruktur dan 
informal dalam berbagai situasi, peneliti juga terlibat dalam forum grup discussion dengan pihak desa dan mitra pendamping CSR. Kemudian untuk mengungkap realitas sosaial yang terjadi, peneliti menggunakan dokumentasi pada setiap kegiatan.

\section{HASIL DAN PEMBAHASAN}

\section{Habitus dalam Implementasi CSR}

Pelaksanaan CSR di PT Tirta Investama - Keboncandi Plant yang sudah sangat terstruktur dan rapi tidak terlepas dari proses pembentukan habitus dari para karyawannya. Program-program CSR yang dijalankan oleh perusahaan seperti Sahabat Mata Air, Arisan Jamban, Micro Finance bisa berjalan dengan baik didasari oleh habitus yang di konstruksi di perusahaan. Pembentukan habitus dimulai dari pembentukan mindset karyawan tentang sustainability, diawali dengan adanya kebijakan- kebijakan yang diterapkan sebagai peraturan. Kemudian dilanjutkan dengan proses memahamkan dan membentuk mindset yang fasilitasi dengan sosialisasi yang berkelanjutan, pelatihan karyawan dan workshop yang terus berevolusi disesuaikan dengan kebutuhan.

Pembentukan habitus seperti mematerikan jargon "dream and nightmare" menjadi dasar perilaku karyawan dalam melaksanakan kinerjanya, dimana terkandung makna jika yang dilakukan sesuai ketentuan maka mimpi bisa diraih, sebaliknya jika ketentuanketentuan yang ada dilanggar, maka mimpi buruk yang akan didapatkan. Mimpi dalam hal ini di maknai sebagaitujuan akhir prusahaan yaitu keberlanjutan, dan mimpi buruk adalah perusahaan berhenti beroperasi. Good habitus tentunya akan menjadi sisi kekuatan tersendiri bagi perusahaan yang mengarah pada yujuan akhir sustainability. Proses pemahaman dan pemaknaan CSR di PT. Tirta Investama-Keboncandi Plant terus berevolusi, dan saat ini arahannya adalah konsen pada sustainability. Jargon dream and nightmare yang dipaterikan pada setiap mindset karyawan merupakan landasan untuk membentuk habitus di seluruh karyawan, dalam mencapai tujuan sustainability. Upaya yang dilakukan oleh perusahaan dalam membentuk habitus pada realitas sosial di perusahaan sejalan dengan yang terdapat dalam konsep habitus pada teori social practice Bourdieu..

\section{Eksistensi Capital Dalam CSR}

Pelaksanaan CSR di PT. Tirta Investama-Keboncandi Plant, program-programnya sudah ditetapkan diawal tahun dan dimasukkan dalam bussiness plan perusahaan, sehingga anggaran yang dibutuhkan untuk merealisasikan program tersebut sudah masuk dalam perencanaan keuangan. Monitoring yang berkelanjutan selalu dilakukan untuk menjamin ketersediaan / eksistensi modal ekonomi selalu tersedia untuk mendanai aktivitas CSR perusahaan. Hal ini sejalan dengan yang terdapat dalam Trilogi Bourdieu, bahwa jika ingin memenangkan sosial practice, maka capital harus eksis untuk mendapatkan kesempatan-kesempatan. Kesempatan-kesempatan disini, bisa diterjemahkan sebagai tujuan dari pelaksanaan aktivitas CSR perusahaan. Tentunya seperti yang disampaikan bahwa ketika membuat budget disusun sampai cost elemennya. Sebelum menentukan cost elemen, basic program harus di laksanakan beserta tujuan dan pencapaiannya pasti sudah ditetapkan.

Kolaborasi antara modal ekonomi, modal sosial dan modal budaya menjadi 
penentu keberhasilan pelaksanaan upaya untuk memenangkan "field" . Artinya bahwa antara modal yang satu dengan yang lain saling berkaitan dan harus terus diupayakan untuk bisa saling mensupport dan menguatkan. Eksistensi modal baik modal ekonomi, modal sosial maupun modal budaya merupakan sebuah rangkaian yang saling berkaitan dan tidak bisa dipisah- pisahkan satu dengan yang lainnya. Modal ekonomi saja tanpa disertai dengan modal sosial dan modal budaya membuat program yang dijalankan tidak akan berhasil begitu juga sebaliknya, jika hanya mengandalkan modal sosial dan budaya tanpa disertai modal ekonomi.

\section{Menyibak Kuasa "Field" dalam CSR}

Corporate sosial responsibility jika digali lebih dalam adalah terkait hubungan antar field-field, penguasaan atas field menjadi kunci keberhasilan pelaksanaan CSR. Ada banyak field yang terlibat dalam pelaksanaan CSR, di Aqua, dalam salah satu pilar "Aqua Lestari" nya sudah disebutkan, dikerjakan bersama-sama oleh karyawan dan masyarakat". Artinya disini bahwa pada pelaksanaan CSR tidak hanya semata-mata dilaksanakan oleh perusahaan sebagai pihak internal (one way) tapi melibatkan pihak eksternal ( masyarakat).

Dalam hal ini masyarakat atau pihak eksternal masih terbagi ke dalam beberapa field yang tentunya memiliki kuasa sendiri dan harus dikuasai oleh perusahaan jika ingin "memenangkan" field nya. Masyarakat sekitar yang berada dalam ring 1 perusahaan, regulator/pemerintahan setempat, konsumen, distributor merupakan field-field yang harus tersentuh "treatment" dalam CSR. Program-program CSR yang dijalankan oleh PT. Tirta Investama - Keboncandi Plant sudah berusaha merangkul semua field yang melingkupinya, baik dari intern maupun ekstern

Pelaksanaan CSR di perusahaan, dari awal disampaikan berdasarkan pada prinsip "based on risk and need". Resiko dan kebutuhan ini melingkupi ranah-ranah yang dalam programnya berusaha untuk dijangkau semuanya. Proses menemukan masalah, menganalisa risk, membuat risk mapping, merencanakan program sampe pelaksanaan program melibatkan banyak field. Penentuan program yang didasari risk mapping juga pasti akan didasari field mana yang mau "disentuh" atau ditaklukkan, masyarakatkah ? pemerintahkah ? konsumenkah ? karyawankah atau shareholder kah?

\section{CSR, CS dan Social Practice Bourdieu}

Dalam Trilogy Bourdieu, dirumuskan sosial practice adalah : habitus $x$ capital + field. Pelaksanaan CSR di PT. Tirta Investama-Keboncandi Plant, sudah mengarah "beyond CSR" yang mengarah pada sustainability, bukan hanya program yang bersifat donasi/charity saja. CSR menjadi alat untuk mencapai mimpi sustainability perusahaan. Berbicara tentang sustainability perusahaan tentu tidak akan terlepas dari profit, perusahaan bisa sustain jika perusahaan bisa modal ekonomi, sosial dan budaya adalah upaya memperoleh "kuasa". Sejalan dengan rumusan Trilogy Bourdieu, apa yang dilakukan oleh perusahaan adalah upaya mengkonstruksi "sosial practice" perusahaan dengan tujuan untuk mencapai sustainability.

Pemahaman CSR awal yang hanya bersifat sosial activity, voluntary, charity, philantropy dan hanya merupakan expense yang membebani Laporan Laba Rugi perusahaan, di rekonstruksi dengan Trilogy Bourdieu sehingga menjadi "new CSR" yang mengarah kepada konsep sustainability, sifatnya sudah mandatory, didasari oleh good habit, 
merupakan capital bukan saja expense dan menjadi "maximum benefit" bagi perusahaan. Implementasi CSR adalah pengejawantahan dari "sosial practice". Ketika perusahaan sudah memenangkan sosial practice nya maka sustainability berada dalam genggaman.

Upaya perusahaan untuk terus membentuk habitus agar memperkuat perolehan modal dan memperoleh kemenangan dalam ranah-ranah di setiap unsur stakeholder adalah upaya yang sejalan dengan rumusan Bourdieu, yaitu rumus memenangkan social practice nya. Salah kaprah pemahaman tentang CSR yang sifatnya adalah voluntary saja, jika ditinjau dari kajian ini, maka sudah seyogyanya CSR dimaknai sebagai hal yang mandatory. Bahkan sampai menyentuh pada sisi kewajiban hakiki sebuah perusahaan jika ingin memperoleh sustainability dalam menjalankan bisnisnya

Memahamkan dan membentuk "people" dalam sebuah realitas sosial bukan hal sekejap yang bisa diupayakan dan kemudian menghasilkan. Sejalan dengan hal tersebut perusahaan terus mengupayakan memperkuat habitus seluruh karyawannya dari semua dari staff sampai ke level top manajerial. Sebuah perjalanan panjang, yang harus terusmenerus diupayakan demi tercapainya mimpi bersama "sustainability". Selanjutnya, planet/ lingkungan, bagi Aqua alam adalah sumber daya utama yang harus dijaga demi kelangsungan hidup usahanya. Sangatlah wajar jika kemudian dalam operasional bisnisnya program-program CSR nya di kuatkan di konservasi lingkungan dan jelas di sebutkan dalam visi dan misi perusahaan. Pembentukan Sahabat Mata Air menjadi penanda keseriusan perusahaan menangani konservasi lingkungan. Di kalangan intern perusahaan bahakan di dengungkan "dosa air" yang di tanamkan pada mindset karyawan, hal ini di maksudkan untuk memotivasi semua elemen perusahaan "aware" akan konservasi lingkungan.

Di program lainnya perusahaan tidak mengesampingkan untuk menguatkan perekonomian masyarakat dengan melakukan program pemberdayaan masyarakat. Kehadiran perusahaan di tengah-tengah masyarakat kemudian mendapatkan pengakuan adalah modal besar bagi perusahaan untuk mendapatkan sumber daya bagi kelanjutan bisnisnya. Kemudian program- program charity dijalankan untuk mengutakan programprogram CSR jangka panjangnya.

Setelah people dan planet bisa dikuasai "ranahnya", pencapaian profit manjadi hal yang secara otomastis mengikuti. Keseimbangan tripple bottom line :people, planet, profit terus diupayakan untuk mencapai sustainability perusahaan. Sehingga tidak mengherankan jika dalam kalangan bisnis air kemasan, Aqua masih menjadi leader, the biggest and strongest. Aqua juga meraih berbagai award dalam pelaksanaan CSR nya.

\section{KESIMPULAN}

PT. Tirta Investama-Keboncandi Plant, memiliki program-program CSR yang sudah tertata dan terprogram dengan baik, baik yang secara rutin maupun insidentil. Program-program yang sudah dijalankan meliputi Sahabat Mata Air, Arisan Jamban, Micro Finance, bukan merupakan program instan yang hanya sekali dijalankan tetapi melalui proses panjang dan melibatkan hubungan sosial diantara para stakeholder untuk mencapai keberlanjutan perusahaan.

Pencapaian sustainability diupayakan dengan pembentukan good habitus yang dibangun di internal perusahaan baik di level operasional maupun managerial. Hal 
berikutnya yang terus diupayakan adalah menjaga eksistensi modal yang tidak hanya modal ekonomi tetapi juga modal sosial dan modal budaya. Good habitus dan eksistensi modal menjadi hal penting untuk penguasaan "field" atas semua pemangku kepentingan baik internal maupun eksternal. Hal ini sejalan dengan teori social practice bourdieu, kemenangan sosial sudah berada dalam genggaman, maka keberlanjutan perusahaan menjadi hal yang mudah untuk di dapatkan.

\section{DAFTAR PUSTAKA}

Aaken, D. van, Splitter, V., \& Seidl, D. (2012). Why Do Corporate Actors Engage in ProSocial Behavior? A Bourdieusian Perspective on Corporate Social Responsibility. SSRN Electronic Journal, 319. https:/ / doi.org/10.2139/ssrn.1970618

Aguinis, H., \& Glavas, A. (2012). What We Know and Don't Know About Corporate Social Responsibility: A Review and Research Agenda. Journal of Management, 38(4), 932-968. https:// doi.org/10.1177/0149206311436079

Alijani, S., \& Karyotis, C. (2016). Finance and Economy for Society : Integrating Sustainability.

Antolín-López, R., Delgado-Ceballos, J., \& Montiel, I. (2016). Deconstructing corporate sustainability: a comparison of different stakeholder metrics. Journal of Cleaner Production, 136, 5-17. https:/ / doi.org/10.1016/j.jclepro.2016.01.111

Baumgartner, R. J. (2014). Managing corporate sustainability and CSR: A conceptual framework combining values, strategies and instruments contributing to sustainable development. Corporate Social Responsibility and Environmental Management, 21(5), 258-271. https:// doi.org/10.1002/csr.1336

Bourdieu, P. (1983). The field of cultural production, or: The economic world reversed. Poetics, 12(4-5), 311-356. https:// doi.org/10.1016/0304-422X(83)90012-8

Bourdieu, P. (1985). The social space and the genesis of groups. Theory and Society, 14(6). https://doi.org/10.1007/BF00174048

Bowen, H. R. (2018). Why Are Businessmen Concerned About Their Social Responsibilities? (Continued). Social Responsibilities of the Businessman, 15(1), 84-105. https://doi.org/10.2307/j.ctt20q1w8f.14

Bruch, H., \& Walter, F. (2005). The keys to rethinking corporate philanthropy. MIT Sloan Management Review, 47(1).

Burke, L., \& Logsdon, J. M. (1996). How Corporate Social Responsibility Pays Off. Long Range Planning, 29(4), 495-502. https://doi.org/10.1016/0024-6301(96)00041-6

Carroll, A. B. (1999). Corporate social responsibility: Evolution of a definitional construct. Business and Society, 38(3), 268-295. https://doi.org/10.1177/000765039903800303

Chen, C. H., \& Wongsurawat, W. (2011). Core constructs of corporate social responsibility: A path analysis. Asia-Pacific Journal of Business Administration, 3(1), 4761. https:/ / doi.org/10.1108/17574321111116397 
Sulis Rochayatun : Memaknai Implementasi Corporate Social Responsibility Menuju Sustainability Dalam Perspektif Social Practice Bourdieu

Clara C. Romero, K., \& L. Lamadrid, R. (2014). Rethinking corporate social responsibility within the sustainability agenda. Journal of Global Responsibility, 5(2), 180-202. https://doi.org/10.1108/jgr-06-2014-0023

Creswell, J. W. (2007). Qualitative Inquiry and Research Design: Choosing Among Five Approaches. In Sage Publication: Vol. 2nd editio. https://doi.org/10.1177/1524839915580941

Creswell, J. W. (2009). Research design - Qualitative, Quantitative and Mixed Method Approach. In Sage Publication: Vol. third edit. https:/ / doi.org/10.2307/1523157

Freeman, R. E. E., \& McVea, J. (2005). A Stakeholder Approach to Strategic Management. SSRN Electronic Journal, January. https:// doi.org/10.2139/ssrn.263511

George Ritzer-Douglas J. Goodman. (2005). Teori Sosiologi Moderen.

Griffin, P. A., \& Sun, E. Y. (2018). Voluntary corporate social responsibility disclosure and religion. Sustainability Accounting, Management and Policy Journal, 9(1), 63-94. https://doi.org/10.1108/SAMPJ-02-2017-0014

Handayati, P., Rochayatun, S., Soetjipto, B. E., Sudarmiatin, Suharto, \& Bukhori, I. (2017). Dismantling social romanticism for corporate social responsibility. International Journal of Applied Business and Economic Research, 15(19).

Hidayah, R., \& Khafid, M. (2016). A Critical Review on Concept Developments of Corporate Social Responsibility Implementation in Enterprises. Review of Integrative Business and Economics Research, 5(1), 340-345.

Hobsbawm, E. (2016). Pierre bourdieu. In New Left Review (Issue 101). https://doi.org/10.15845/praxeologi.v3i0.3158

Huda, M., Mulyadi, D., Hananto, A. L., Nor Muhamad, N. H., Mat Teh, K. S., \& Don, A. G. (2018). Empowering corporate social responsibility (CSR): insights from service learning. Social Responsibility Journal, 14(4), 875-894. https:/ / doi.org/10.1108/SRJ-042017-0078

Jenkins, R. (1992). Pierre Bourdieu: Key Sociologists. In Routledge: London Ka \ug $\backslash$ itç $\backslash i b a \backslash c s \backslash i$, Ç.(1982).Sex Roles And Value of Children and Fertility In Turkey In Sex Roles, Family, and Community In Turkey Ka $\backslash u g \backslash i t c ̧ \backslash i b a \mid c s \backslash i$, Ç.(ed), Indiana University. Turkish Studies (Vol. 3). file:///Users/jeltsjestobbe/Documents/SENTE VERSIES/LITERATUUR

PROMOTIETIJD.sente6lib/Contents/Attachments/Jenkins/1992/Key Sociologists_ Pierre Bourdieu/Jenkins 1992 Key Sociologists Pierre Bourdieu.pdf

Krisdinanto, N. (2016). Pierre Bourdieu, Sang Juru Damai. KANAL: Jurnal Ilmu Komunikasi, 2(2), 189. https:// doi.org/10.21070/kanal.v2i2.300

Marrewijk, M. Van. (2003). Concepts and definitions of CSR and corporate sustainability: Between agency and communion. Journal of Business Ethics, 44, 95-105. 
Sulis Rochayatun : Memaknai Implementasi Corporate Social Responsibility Menuju Sustainability Dalam Perspektif Social Practice Bourdieu

Matten, D., \& Moon, J. (2008). "Implicit" and "explicit" CSR: A conceptual framework for a comparative understanding of corporate social responsibility. Academy of Management Review, 33(2), 404-424. https:/ / doi.org/10.5465/AMR.2008.31193458

McWilliams, A., \& Siegel, D. (2000). Corporate social responsibility and financial performance: Correlation or misspecification? Strategic Management Journal, 21(5). https://doi.org/10.1002/(SICI)1097-0266(200005)21:5<603::AID-SMJ101>3.0.CO;2-3

McWilliams, A., \& Siegel, D. S. (2011). Creating and capturing value: Strategic corporate social responsibility, resource-based theory, and sustainable competitive advantage. Journal of Management, 37(5), 1480-1495. https:/ / doi.org/10.1177/0149206310385696

Moura-Leite, R. C., \& Padgett, R. C. (2011). Historical background of corporate social responsibility. Social Responsibility Journal, 7(4), 528-539. https://doi.org/10.1108/1747111111117511

Perrini, F., Russo, A., \& Tencati, A. (2007). CSR strategies of SMEs and large firms. Evidence from Italy. Journal of Business Ethics, 74(3), 285-300. https://doi.org/10.1007/s10551-006-9235-x

Pomare, C. (2018). A multiple framework approach to sustainable development goals (SDGs) and entrepreneurship. Contemporary Issues in Entrepreneurship Research, 8, 1131. https://doi.org/10.1108/S2040-724620180000008006

Russo, A., \& Perrini, F. (2010). Investigating stakeholder theory and social capital: CSR in large firms and SMEs. Journal of Business Ethics, 91(2), 207-221. https://doi.org/10.1007/s10551-009-0079-z

Schaltegger, S., Bennett, M., \& Burrit, R. (2006). Corporate Sustainability - the Basis of Sustainability Accounting and Reporting. In Sustainability Accounting and Reporting.

Spence, L. J. (2007). CSR and Small Business in a European Policy Context: The Five "C" s of CSR anf Small Business Research. Science $\mathcal{E}$ Sports, 22(3-4), 184-185. https://doi.org/10.1016/j.scispo.2007.06.005

Wapshott, R. (2017). Pierre Bourdieu, Organisation, and Management. Personnel Review, 46(2), 449-450. https://doi.org/10.1108/pr-08-2016-0203

Webb, J., Schirato, T., \& Danaher, G. (2020). Understanding Bourdieu. Understanding Bourdieu, 1-210. https:/ / doi.org/10.4324/9781003118305 